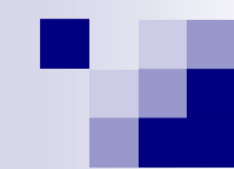

\section{Emerging Science Journal}

(ISSN: 2610-9182)

Vol. 5, Special Issue "COVID-19: Emerging Research", 2021

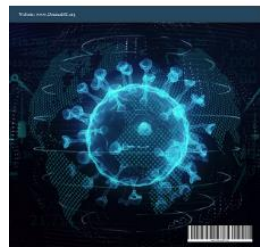

\title{
The Advantages and Disadvantages of E-working: An Examination using an ALDINE Analysis
}

\author{
Michal Beňo ${ }^{1 *}$ \\ ${ }^{1}$ Institute of Technology and Business in Ceske Budejovice, Ceske Budejovice 370 01, Czech Republic
}

\begin{abstract}
Objectives: Working remotely comes with significant pros and cons with different demands for individuals or teams. E-working has been the object of much interest, but there has been little research on the statistical difference between its advantages and disadvantages. Research Question: Is there a significant statistical difference between them? Methods: The present research, however, goes one step further and identifies the statistical difference between them. Firstly, we evaluated the positive and negative aspects with a meta-analysis of 20 studies and, secondly, we used a nonparametric test, namely the Wilcoxon Rank Test, for further analysis across pros and cons. Findings: We found that e-working provides more positive than negative ones. A binomial test showed that most studies (more than 50\%) mention flexibility, productivity and efficiency, satisfaction and WLB as benefits. Novelty/improvement: E-working is a triple win option. There are many advantages to working remotely, but this method of work does not suit everyone. Our results provide building blocks for a more complete theoretical and practical treatment of e-working for the future. But COVID-19, technology advancement and a connected global world show clearly that eworking will play a crucial role in the future of the workplace.
\end{abstract}

\section{Keywords:}

ALDINE; Meta-analysis; Wilcoxon Rank Test;

Advantages and Disadvantages;

E-working; COVID-19.

\section{Article History:}

$\begin{array}{llll}\text { Received: } & 26 & \text { December } & 2020 \\ \text { Revised: } & 16 & \text { February } & 2021 \\ \text { Accepted: } & 18 & \text { March } & 2021 \\ \text { Published: } & 19 & \text { April } & 2021\end{array}$

\section{1- Introduction}

Basically, e-work means the utilisation of ICT rather than commuting to work [1]. Work-family balance, as well as less commuting, are among the factors put forward to explain the interest in e-working. According to Hossen et al. [2], Work-Life Balance or Work-Family Conflict is one of the much talked about issues in the modern business arena and among the stakeholders in business. Despite the growing trend of automation and robotics, the human factor remains important. We observe an increased demand for e-working in today's knowledge-based economy.

An organisation's ability to achieve and sustain a competitive advantage depends largely on the specific skills and knowledge supplied by its employees, its human resources [3]. Daniels et al. [4] divide the advantages/disadvantages into three groups - organisational, individual and societal. In a similar way, we set pros and cons for employee, employer and society. To increase the employees' psychological health, job satisfaction and performance, organisations increasingly offer flexibility [5].

It remains unclear, however, whether the advantages outweigh the disadvantages when all the factors are taken into account. The spread of this kind of work within the European Union is unequal, ranging from the highest occurrence in the Netherlands, Luxembourg, Finland and Austria, to the lowest in Bulgaria, Romania, Cyprus and Croatia [6]. In the past, challenging problems and unknown risks faced by employers and employees made e-working difficult. But

\footnotetext{
*CONTACT: Beno@mail.vstecb.cz
}

DOI: http://dx.doi.org/10.28991/esj-2021-SPER-02

(C) 2021 by the authors. Licensee ESJ, Italy. This is an open access article under the terms and conditions of the Creative Commons Attribution (CC-BY) license (https://creativecommons.org/licenses/by/4.0/). 
now the situation has changed. We argue that the perceived benefits and shortcomings for employees can be different from those for employers, and vice versa. Furthermore, we add that managers who do e-work themselves have more experience and a greater understanding of the pros and cons arising from this kind of work.

The principal objective of this study was to explore the advantages and disadvantages of e-working. The aim was to determine possible positive as well as negative aspects, which were suggested in the meta-analysis through the Wilcoxon Rank Test to find out whether there is a statistical difference between them. Firstly, we explain the concept e-working. The next section briefly outlines the methodology used in this research. Then follows a section presenting an overview of the results and a discussion. The last section gives the conclusions.

\section{2- Conceptual Framework: E-working}

The conceptual framework for this research study is an explanation of e-working. After many years of reviewing literature and conducting empirical research on this topic, it is quite clear that this phenomenon is approachable in numerous ways and can be applied to a range of objectives. There are numerous definitions of the phenomenon. The classic definition of teleworking is outdated [7]. Today, institutions, academics, politicians and humankind combine adjectives such as informative, electronic, digital, tele-, virtual, cyber, flexible, global, nomadic, networked or simply e-. The concept of e-working is replacing a range of different terms, such as "teleworking, telecommuting, networking, digital nomad, nomadic work, flexi space, flexitime," which seek to describe the ways in which modern information and communications technologies have made it possible for information processing to be carried out remotely.

E-working uses information and communication technology to allow work to be carried out independently of location [7], and it includes the e-worker - working from home or remote office (full- or part-time), teleworker - parttime at home and part-time in the office or mobile e-worker (on the move) - outside the home or office using modern ICT. We define e-working as an activity where an employee works part- or full-time at home, partly from home or on the road and the rest of the time at the workplace, possibly in different countries. This kind of work includes off-thejob work, remote desktop log-on, sending and receiving e-mails, data and files and developing ideas and selling products and services remotely. An e-worker is any employee who carries out e-working as defined above in an eorganisation in the Internet cultural era.

E-working can bring substantial benefits for the employer, by reducing overheads, increasing productivity and improving retention; and for the employee, by balancing work and other aspects of life, better access to employment, and for society, by bringing significant economic and social benefits as a result of reducing the carbon footprint.

\section{3- Methodology}

The flow chart below shows the steps that have been taken in doing this research (See Figure 1).

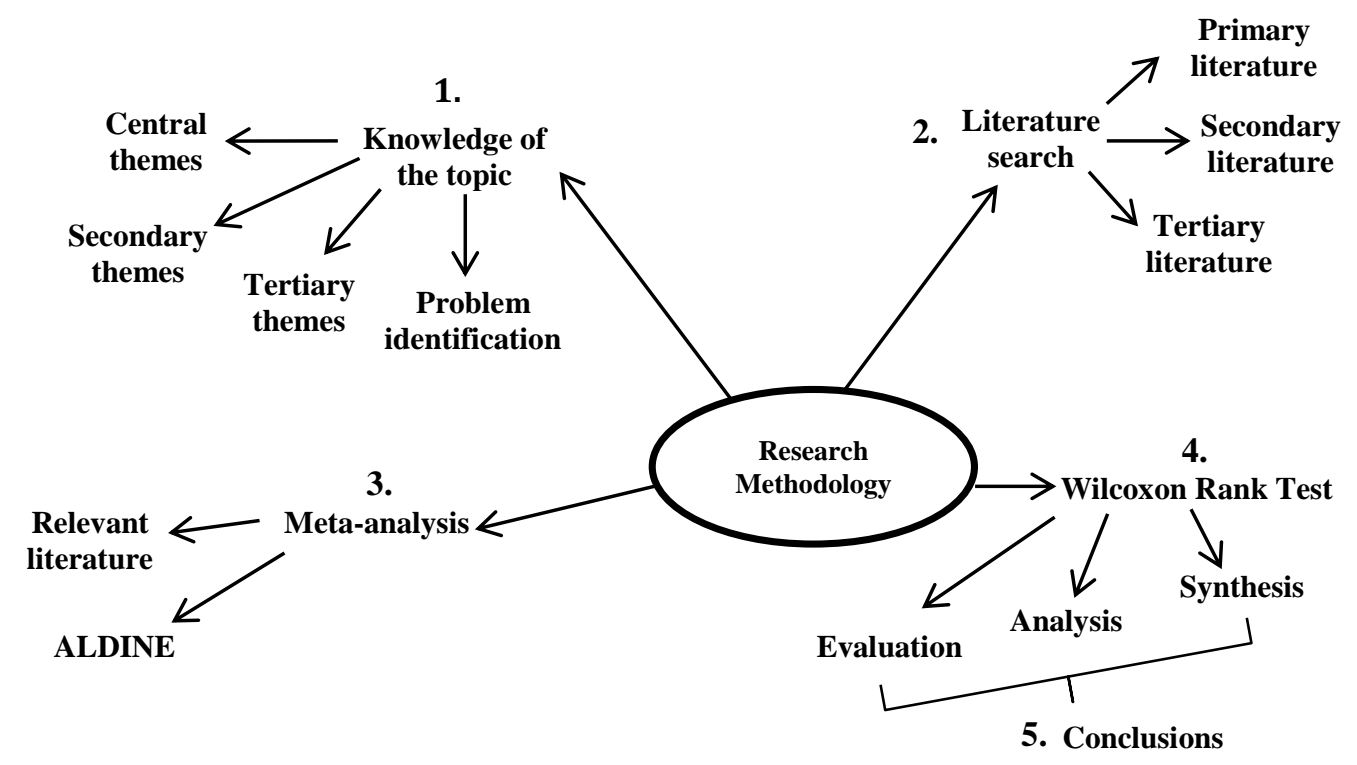

Figure 1. Flow chart of the research methodology.

The first step also includes audience targeting (having a clear idea for whom the paper is intended). Before starting the literature search, it is important to develop a theoretical framework, which includes writing down the research questions and highlighting subjects (including synonyms) and keywords (see second step). The third step consists of meta-analysis. Meta-analysis summarises and synthesises results from various studies of a particular issue [8]. Combining the information from a large number of studies can provide a more accurate assessment of the existence of 
the strength of the relationship [9] as against the results of one study. We conducted a search for relevant literature in the Scopus, Google Scholar, WOS and EBSCO databases, using keywords that represent e-working, such as flexible work schedule, flextime, flexitime, flexible scheduling, telecommuting, telework, remote work, work at home, virtual work, flexplace and home office. If a study met the inclusion criteria but did not report the necessary statistical data, the author was contacted. To be included in our meta-analysis, a study had to meet the following criteria: a) articles published after 1991; b) relationship of flexible work arrangements (FWA) and outcomes; c) articles written in English; d) appropriate sample size; e) the sample must include employer, employee and society; and f) must not be a meta-analysis nor a review or literature research article. We further extracted the following information from these studies and divided it into six components, which we labelled with the English word ALDINE (Author, Land, Decade, Issue, $\mathbf{N}$ and Evaluation). This stands for a book printed by the Aldine press [10]. Moreover, the authors of the paper have employed a non-parametric, Wilcoxon Rank Test for data analysis using a quantitative approach. This tool will be used to assist in the analysis of the data collected during the research and will allow the researcher to determine whether the number of advantages and disadvantages differ statistically. Finally, our aim is to understand the correlation between arguments for e-working and against it. The last step consisted of writing up all the data and summarising a large volume of research within an area and discussing and formulating the conclusions.

\section{4- Results and Discussions}

E-working is linked to the proliferation and advance of telecommunications technology. In the past, most office arrangements required employees to be physically present to perform their jobs. Today's permanently connected, instant-access environment has blurred the lines between the physical office and the place where work is actually done. The workplace has become a digital environment, and employees are communicating and collaborating in different ways [7].

We found a total 3208 potentially relevant studies. The final study selection took place in two steps (see Figure 2). Firstly, we screened the abstracts to decide whether the full text should be reviewed in detail. Many studies were excluded because of inappropriate participants, samples or by being characterised as meta-analysis, reviews or literature research articles. After screening the abstracts of the search reference list (43), 97 studies remained. These studies were screened in detail. If a study met the inclusion data but the necessary statistical data were missing, we contacted the author (16). Finally, 20 articles were selected for our meta-analysis.

\begin{tabular}{|c|c|c|c|c|}
\hline $\begin{array}{c}\text { Literature } \\
\text { Search }\end{array}$ & \multicolumn{3}{|c|}{ Scopus, Google Scholar, Web of Science, } & \\
\hline $\begin{array}{c}\text { Selection } \\
\text { Criteria }\end{array}$ & \multicolumn{3}{|c|}{$\begin{array}{ll}\text { - Articles published after 1991 } & \text { - The sample must include } \\
\text { - Relationship of Flexible Work } & \text { employer, employee and } \\
\text { Arrangements (FWA) and outcomes } & \text { society } \\
\text { - Articles written in English } & \begin{array}{l}\text { Neither meta-analysis, } \\
\text { nor reviews and literature } \\
\text { - Appropriate sample size }\end{array} \\
\text { research studies }\end{array}$} & $\begin{array}{l}\text { Search of } \\
\text { reference } \\
\text { list: } 43\end{array}$ \\
\hline & \multicolumn{3}{|c|}{ Preselected studies: 97} & \\
\hline $\begin{array}{c}\text { Inclusion } \\
\text { Criteria }\end{array}$ & \multicolumn{3}{|l|}{$\begin{array}{l}\text { - Appropriate stat } \\
\text { - Quantitative and } \\
\text { - Correlations } \\
\text { - Sample sizes }\end{array}$} & $\begin{array}{l}\text { Request to the } \\
\text { authors: } 16\end{array}$ \\
\hline $\begin{array}{l}\text { Included } \\
\text { Studies }\end{array}$ & $\begin{array}{l}\text { Selected studies } \\
\text { for meta- } \\
\text { analysis: } 20\end{array}$ & $\begin{array}{l}\text { Excluded studies: } 77 \\
\text { - did not have } \\
\text { enough data: } 14 \\
\text { - Missing year: } 7 \\
\text { - Other language: } 5\end{array}$ & $\begin{array}{l}\text { - Meta-analysis, reviews } \\
\text { research: } 36 \\
\text { - Too small sample: } 5 \\
\text { - Missing pdf document }\end{array}$ & $\begin{array}{l}\text { iterature } \\
0\end{array}$ \\
\hline
\end{tabular}

Figure 2. Schematic diagram of literature research and included studies.

Table 1 summarises the characteristics of the primary studies included in this ALDINE meta-analysis. It shows the measured data and outcomes of each particular primary study. There was no uniform scale used in the results of any study. 
Table 1. ALDINE.

\begin{tabular}{|c|c|c|c|c|c|}
\hline Author & Land & Decade & Issue & $\mathbf{N}$ & Evaluation \\
\hline Beňo (2018) [11] & SK & 2018 & $\begin{array}{l}\text { An Empirical Study on Teleworking } \\
\text { Among Slovakia's Office-Based Academics }\end{array}$ & 125 & $\begin{array}{l}\text { Flexibility, less commuting, productivity, } \\
\text { WLB isolation, family conflicts, technical } \\
\text { difficulties }\end{array}$ \\
\hline Beňo (2018) [12] & World & 2018 & $\begin{array}{l}\text { Working in the Virtual World - an approach } \\
\text { to the Home Office Business Model } \\
\text { Analysis }\end{array}$ & 308 & Flexibility, WLB, satisfaction \\
\hline Bentley (2013) [13] & $\mathrm{NZ}$ & 2013 & The Trans-Tasman Telework Survey & 1827 & Productivity, satisfaction isolation, stress \\
\hline Baruch (2000) [14] & GB & 2002 & $\begin{array}{l}\text { Teleworking benefits and pitfalls as } \\
\text { perceived by professionals and managers }\end{array}$ & 62 & $\begin{array}{l}\text { WLB and quality of work, cost reduction, } \\
\text { efficiency, productivity, integration of } \\
\text { disabled people, eco-friendly aspiration and } \\
\text { career perception, culture of trust }\end{array}$ \\
\hline $\begin{array}{l}\text { Duxbury et al. (1998) } \\
{[15]}\end{array}$ & $\mathrm{CA}$ & 1998 & $\begin{array}{l}\text { Telework and the balance between work } \\
\text { and family: Is telework part of the problem } \\
\text { or part of the solution? }\end{array}$ & 138 & $\begin{array}{l}\text { Productivity, multiple concentration, WLB } \\
\text { stress, overwork, work-life balance }\end{array}$ \\
\hline $\begin{array}{l}\text { Guarino and } \\
\text { Bouffard [17] }\end{array}$ & US & 2002 & $\begin{array}{l}\text { Evaluating the success of Telecommuting at } \\
\text { the Census Bureau }\end{array}$ & 500 & $\begin{array}{l}\text { Less commuting, WLB, flexibility } \\
\text { communication, gender diversity and } \\
\text { rewards }\end{array}$ \\
\hline $\begin{array}{l}\text { Hartman et al. (1991) } \\
\text { [18] }\end{array}$ & US & 1991 & $\begin{array}{l}\text { An Investigation of selected variables } \\
\text { affecting telecommuting productivity and } \\
\text { satisfaction }\end{array}$ & 97 & Productivity and satisfaction overtime \\
\hline $\begin{array}{l}\text { Hawkins et al. (1999) } \\
\text { [19] }\end{array}$ & US & 1999 & $\begin{array}{l}\text { The effectiveness of Telecommuting for the } \\
\text { Employee, Employer, and Society }\end{array}$ & 108 & $\begin{array}{l}\text { Flexibility, productivity, eco-friendly, } \\
\text { WLB, cost reduction, retention of workers, } \\
\text { less distraction isolation, lack of access to } \\
\text { information, co-workers' indignation, } \\
\text { hardware costs, personal expenses }\end{array}$ \\
\hline Hill et al. (2006) [20] & US & 2006 & $\begin{array}{l}\text { Influences of the Virtual Office on Aspects } \\
\text { of Work and WLB }\end{array}$ & 246 & $\begin{array}{l}\text { Productivity, morality, flexibility overtime, } \\
\text { teamwork }\end{array}$ \\
\hline $\begin{array}{l}\text { Hornung and Glaser } \\
\text { (2009) [22] }\end{array}$ & $\mathrm{DE}$ & 2009 & $\begin{array}{l}\text { Home-Based Telecommuting and Quality of } \\
\text { Life: Further Evidence on an Employee- } \\
\text { Oriented Human Resource Practice }\end{array}$ & 1008 & $\begin{array}{l}\text { Satisfaction (autonomy), WLB conflicts - } \\
\text { work and private life }\end{array}$ \\
\hline $\begin{array}{l}\text { Masuda et al. (2011) } \\
\text { [23] }\end{array}$ & $\begin{array}{l}\text { Asia } \\
\text { Latin America } \\
\text { Anglo }\end{array}$ & 2012 & $\begin{array}{l}\text { Flexible Work Arrangements Availability } \\
\text { and their Relationship with Work- to- } \\
\text { Family Conflict, Job Satisfaction, and } \\
\text { Turnover Intentions: A Comparison of } \\
\text { Three Country Clusters }\end{array}$ & 3198 & Flexibility, satisfaction culture \\
\hline $\begin{array}{l}\text { Mungania et al. } \\
\text { (2016) [24] }\end{array}$ & $\mathrm{KE}$ & 2016 & $\begin{array}{l}\text { Influence of Flexible Work Arrangements } \\
\text { on Performance of the Banking Industry in } \\
\text { Kenya }\end{array}$ & 36212 & $\begin{array}{l}\text { Productivity, flexibility conflicts - work } \\
\text { and private life, stress, depression }\end{array}$ \\
\hline Pyöriä (2003) [25] & FI & 2003 & $\begin{array}{l}\text { Knowledge work in distributed } \\
\text { environments: issues an illusions }\end{array}$ & 1775 & $\begin{array}{l}\text { Flexibility, WLB, image, increased } \\
\text { employment, integration of disabled people, } \\
\text { eco-friendly disappearance of the } \\
\text { boundaries between work and private life, } \\
\text { workaholism, security }\end{array}$ \\
\hline $\begin{array}{c}\text { Raghuram and } \\
\text { Wiesenfeld (2004) } \\
{[26]}\end{array}$ & US & 2004 & $\begin{array}{l}\text { Work-Nonwork Conflict and Job Stress } \\
\text { among Virtual Workers }\end{array}$ & 756 & $\begin{array}{l}\text { Stress, organisational connectivity, } \\
\text { flexibility the disappearance of the } \\
\text { boundaries between work and private life }\end{array}$ \\
\hline Stavrou (2005) [27] & EU & 2005 & $\begin{array}{l}\text { Flexible Work Bundles and Organizational } \\
\text { Competitiveness: A Cross-National Study } \\
\text { of the European Work Context }\end{array}$ & 2811 & Productivity, absence reduction of turnover \\
\hline $\begin{array}{l}\text { Ten Brummelhuis et } \\
\text { al. (2012) [28] }\end{array}$ & NL & 2010 & $\begin{array}{l}\text { Effective work-life balance support for } \\
\text { various household structures }\end{array}$ & 482 & Productivity, WLB family background \\
\hline Tremblay (2002) [29] & $\mathrm{CA}$ & 2002 & $\begin{array}{l}\text { Balancing Work and Family with } \\
\text { Telework? Organizational Issues and } \\
\text { Challenges for Women and Managers }\end{array}$ & $\begin{array}{c}10590 \\
163\end{array}$ & $\begin{array}{l}\text { Satisfaction, flexibility, less commuting } \\
\text { isolation, workaholism, conflicts }\end{array}$ \\
\hline
\end{tabular}


We stress that it does not depend on where you work, but rather on the results of the work done. E-working is becoming an important feature of the working environment with multiple implications for the whole society. The world is changing at an incredible rate. Today's environment is characterised by changes, complexity, interconnectivity and technological development. New challenges come from the external environment (technological, social, economic, educational, etc.), which requires greater flexibility and innovation, as well as an internal organisational environment where employees demand greater autonomy and self-expression. Thus, the features of the new economy can be summed up as the importance of knowledge, the development of flexible structures, the lesser importance of borders and unusual entrepreneurship. The use of new technologies to work outside the office could change proven workplace concepts. In order to formulate and not only respond to these changes, we need to understand what e-working offers to workers, employers and the wider society. In the introduction, we highlighted the unequal spread of e-working within the European Union. Thanks to the rapid development of technology and the widespread use of the Internet, it has undergone a huge change in the way people do business, work and collaborate. E-working means a modern form of work at anytime and anywhere.

The worldwide boom of working is driven by business demands to maximise flexibility in job placement and timing, the ability of e-working to meet family and work demands, continued competition and innovation to cut costs, change workforce ideas and expectations, and reduce the ecological footprint. Our analysis examines our main question about whether e-working is considered a winning strategy that has tremendous potential for employees, employers and society. From ALDINE data, we analysed the total number of advantages and disadvantages, as shown in Table 2.

Table 2. Analysis of advantages and disadvantages.

\begin{tabular}{ccc}
\hline Study & Advantages & Disadvantages \\
\hline 1 & 4 & 3 \\
2 & 3 & 0 \\
3 & 2 & 2 \\
4 & 5 & 2 \\
5 & 3 & 2 \\
6 & 4 & 3 \\
7 & 3 & 2 \\
8 & 2 & 1 \\
9 & 7 & 5 \\
10 & 3 & 2 \\
11 & 1 & 1 \\
12 & 2 & 0 \\
13 & 2 & 2 \\
14 & 2 & 2 \\
15 & 5 & 3 \\
16 & 2 & 1 \\
17 & 2 & 2 \\
18 & 2 & 1 \\
19 & 3 & 3 \\
20 & 3 & 3 \\
\hline & &
\end{tabular}

By means of non-parametric pair test, we determined whether the number of advantages and disadvantages differ statistically. We chose Wilcoxon's rank test as a non-parametric test, and the results of this test can be seen in Table 3.

Table 3. Ranks.

\begin{tabular}{lcccc}
\hline & N & Mean rank & Sum of ranks \\
\hline & Negative ranks & $13^{\mathrm{a}}$ & 7.00 & 91.00 \\
$\begin{array}{l}\text { disadvantages_total } \\
\text { - advantages_total }\end{array}$ & Positive ranks & $0^{\mathrm{b}}$ & 0.00 & 0.00 \\
& Ties & $7^{\mathrm{c}}$ & \\
\hline Total & 20 & \\
\hline${ }^{\text {a disadvantages_total < advantages_total }}$ & & \\
${ }^{\mathrm{b}}$ disadvantages_total $>$ advantages_total \\
${ }^{\mathrm{c}}$ disadvantages_total $=$ advantages_total
\end{tabular}


The P-value of the test is a difference of less than 0.05 ( $\mathrm{Sig},=0.001$, see Table 4 ) between the number of advantages and disadvantages. Therefore it is a statistically significant difference. This means that more use is made of the advantages in the studies than the disadvantages.

Table 4. Test statistics ${ }^{\text {a }}$.

\begin{tabular}{cc}
\hline & disadvantages_total - advantages_total \\
\hline Z & $-3.270^{\mathrm{b}}$ \\
Asymp. Sig. (2-tailed) & 0.001 \\
\hline${ }^{\mathrm{a}}$ Wilcoxon Signed Rank Tests & \\
${ }^{\mathrm{b}}$ based on positive ranks &
\end{tabular}

Furthermore, we examined the frequency of advantages (shown in bold) and disadvantages, as highlighted in Table 5 .

Table 5. Advantages and disadvantages, frequencies.

\begin{tabular}{|c|c|c|c|c|}
\hline & & $\mathbf{N}$ & $\%$ & $\%$ of Cases \\
\hline \multirow{18}{*}{$\begin{array}{l}\text { disadvantages_total } \\
\text { - advantages_total }\end{array}$} & flexibility & 11 & 11.00 & 55.00 \\
\hline & productivity, efficiency & 13 & 13.00 & 65.00 \\
\hline & satisfaction & 8 & 8.00 & 40.00 \\
\hline & WLB & 10 & 10.00 & 50.00 \\
\hline & less commuting & 4 & 4.00 & 20.00 \\
\hline & cost reduction & 3 & 3.00 & 15.00 \\
\hline & eco-friendly & 3 & 3.00 & 15.00 \\
\hline & image, morality, concentration & 4 & 4.00 & 20.00 \\
\hline & employment, acquisition, retention & 4 & 4.00 & 20.00 \\
\hline & isolation & 5 & 5.00 & 25.00 \\
\hline & conflicts & 7 & 7.00 & 35.00 \\
\hline & technical difficulties, hardware, security & 3 & 3.00 & 15.00 \\
\hline & stress, depression & 5 & 5.00 & 25.00 \\
\hline & overtime, workaholism, burn-out & 4 & 4.00 & 20.00 \\
\hline & culture, family background & 8 & 8.00 & 40.00 \\
\hline & uncertain legal environment, career & 3 & 3.00 & 10.00 \\
\hline & reduction of turnover & 2 & 2.00 & 10.00 \\
\hline & team work & 3 & 3.00 & 15.00 \\
\hline Total & & 100 & 100.00 & 500.00 \\
\hline
\end{tabular}

Productivity and efficiency were mentioned in $65 \%$ of the cases, flexibility in 55\%, WLB in 50\% and satisfaction in $40 \%$. Shafizadeh et al. [31] claim that working from home increases productivity, but Monteiro et al. [32] claim the opposite. Other studies found evidence of a positive association between flextime and employee well-being [33, 34]. E-working mainly affects culture and family background (40\%), conflicts (35\%), isolation, stress and depression, with 25\%. Lupu [35] also mentions some drawbacks, namely employee isolation and limitation of normal interaction with colleagues and difficulty in organising union activities. Ford and Butts [36] express the situation as: out of sight, out of mind.

Subsequently, we compared the proportion of benefits in the studies, as they were named more than the disadvantages. The binomial test (see Table 6) showed that most studies (significantly more than 50\%) mention flexibility, productivity and efficiency, satisfaction and WLB as advantages. We did not perform this test for disadvantages because the proportion of each disadvantage in the studies was less than $50 \%$. 
Table 6. Hypothesis test summary.

\begin{tabular}{|c|c|c|c|c|}
\hline No. & Null hypothesis & Test & Sig. & Decision \\
\hline 1 & $\begin{array}{l}\text { The categories defined by flexibility }=1.0 \text { and } 0.0 \text { occur } \\
\text { with probabilities } 0.5 \text { and } 0.5\end{array}$ & One-sample binomial test & $0.824^{1}$ & Retain the null hypothesis \\
\hline 2 & $\begin{array}{l}\text { The categories defined by productivity, efficiency }=1.0 \\
\text { and } 0.0 \text { occur with probabilities } 0.5 \text { and } 0.5\end{array}$ & One-sample binomial test & $0.263^{1}$ & Retain the null hypothesis \\
\hline 3 & $\begin{array}{l}\text { The categories defined by satisfaction }=1.0 \text { and } 0.0 \text { occur } \\
\text { with probabilities } 0.5 \text { and } 0.5\end{array}$ & One-sample binomial test & $0.503^{1}$ & Retain the null hypothesis \\
\hline 4 & $\begin{array}{l}\text { The categories defined by WLB }=1.0 \text { and } 0.0 \text { occur with } \\
\text { probabilities } 0.5 \text { and } 0.5\end{array}$ & One-sample binomial test & $1.000^{1}$ & Retain the null hypothesis \\
\hline 5 & $\begin{array}{l}\text { The categories defined by less commuting }=1.0 \text { and } 0.0 \\
\text { occur with probabilities } 0.5 \text { and } 0.5\end{array}$ & One-sample binomial Test & $0.012^{1}$ & Reject the null hypothesis \\
\hline 6 & $\begin{array}{l}\text { The categories defined by cost reduction }=1.0 \text { and } 0.0 \\
\text { occur with probabilities } 0.5 \text { and } 0.5\end{array}$ & One-sample binomial test & $0.003^{1}$ & Reject the null hypothesis \\
\hline 7 & $\begin{array}{l}\text { The categories defined by eco-friendly }=1.0 \text { and } 0.0 \text { occur } \\
\text { with probabilities } 0.5 \text { and } 0.5\end{array}$ & One-sample binomial test & $0.003^{1}$ & Reject the null hypothesis \\
\hline 8 & $\begin{array}{l}\text { The categories defined by image, morality, concentration }= \\
1.0 \text { and } 0.0 \text { occur with probabilities } 0.5 \text { and } 0.5\end{array}$ & One-sample binomial test & $0.012^{1}$ & Reject the null hypothesis \\
\hline 9 & $\begin{array}{l}\text { The categories defined by employment, acquisition, } \\
\text { retention }=1.0 \text { and } 0.0 \text { occur with probabilities } 0.5 \text { and } 0.5\end{array}$ & One-sample binomial test & $0.012^{1}$ & Reject the null hypothesis \\
\hline
\end{tabular}

Not only employees and employers win with e-working, but also the whole society. However, despite positive effects, company management still has some concerns regarding supervision and the immediate availability of workers in certain situations. Flexible organisations that can redesign the workplace to take advantage of e-working will achieve potentially significant gains, in addition to addressing congestion, poor air quality and many other problems. In a context of globalisation and fierce competition, organisations strive to offer good quality products/services at the lowest possible price. In this context, they can exploit the potential of e-working through a skilled workforce that requires lower costs and which can provide increased flexibility. This type of work has a significant economic, social and environmental impact; which also affects the international division of labour. It also offers the opportunity for developing countries to improve and become competitive [37]. The authors further stress that e-working is a very strong and productive tool in the equation for worldwide balance.

With the current Covid-19 situation, employers everywhere are considering switching to a distributed team culture and have been literally forced by circumstances to try the remote work experiment. E-working means changing the central location of work away from the usual office premises. Managers are asking whether e-working is a realistic option for the company's business model? Does it fit the culture? Does the potential cost saving outweigh the risks? There is no one-size-fits all answer. However, there is a lot of middle ground between full-time on-site work and hybrid or full-time e-working. Research shows that letting a single employee work from home can save a business $\$ 10$ 000 [38]. Furthermore, this kind of work has a positive impact on environment. A part-time e-working policy could make a real impact on the environment that we all share. According to 2019 research by Global Workplace Analytics, if everyone with the ability and desire to work remotely did so just $50 \%$ of the time, "the greenhouse gas reduction would be the equivalent of taking the entire New York State workforce permanently off the road." That's because $29 \%$ of greenhouse gas emissions come from the transportation sector [39]. Furthermore, according to the Garg and Rijst results [40], the majority of employees were willing to work from home. Their data also confirm the savings to the company and to the employees.

Working from home is not feasible for every person or every type of job. Furthermore, as the coronavirus maintains its World Health Organisation pandemic status of, companies are advising their employees to work from home, but some industries are not prepared for this. As technology evolves, many of the barriers that have traditionally limited eworking continue to disappear. The tedious standard of spending 38-40 hours a week sitting in a cubicle is fading as both employers and workers embrace the benefits associated with this kind of work. As a result of the authors' analysis, it can be concluded that there are several benefits that employers, employees and society should take advantage of. Raišienè et al. [41] stress that the virtual way of working is becoming increasingly popular due to its potential for cost savings; it is also a way for an organisation to be more agile and adapt to crises such as global pandemics. Having flexibility, while also having a balanced work and private life and being productive, is a big attraction for many people. But a pandemic affects many employees' psychology and daily life adversely, which has a negative influence on some employees and on their productivity [42]. But one has to be careful that the workplace does not invade home life excessively, so that one ends up working longer. E-working eliminates commuting and distractions that may decrease productivity. With no idle chatter around the water cooler or slipping out of the office early to beat the rush hour, employees will be productive for more hours in the day. 


\section{5- Conclusion}

In conclusion, we found that the advantages outweigh the disadvantages, with results similar to those of the Harpaz [43] study. The study findings indicate that e-working provides more positive aspects than negative ones. A binomial test showed that most studies (more than 50\%) mention flexibility, productivity and efficiency, satisfaction and WLB as benefits. This study's results are in line with those of a study by Tremblay and Thomsin [44]. E-working is a triple win. But it indicates that not all sectors, individuals or professions are able to work in this way.

There are a few limitations when using Wilcoxon Signed-Rank test statistics. Firstly, the sample size may range from a few to several hundred. Furthermore, if one is primarily interested in differences in location between the two distributions, the Wilcoxon test has the disadvantage of reacting to other differences of distribution. Thirdly, the disadvantage of the Wilcoxon Signed Rank Test over the Signed test is that more assumptions are required.

As already mentioned, with the coronavirus crisis many companies and institutions had to change to e-work and home offices - suddenly and unexpectedly this has become the solution even for those who hesitated about its implementation or were not wholly persuaded about the positive features of this kind of work. E-working has become a must in 2020 much faster than in the previous 20 years. This creates an unprecedented field for further research in this area, in qualitative and in quantitative terms.

\section{6- Declarations}

\section{6-1-Data Availability Statement}

The data presented in this study are available on request from the corresponding author.

\section{6-2-Funding}

The authors received no financial support for the research, authorship, and/or publication of this article.

\section{6-3- Conflicts of Interest}

The author declares that there is no conflict of interests regarding the publication of this manuscript. In addition, the ethical issues, including plagiarism, informed consent, misconduct, data fabrication and/or falsification, double publication and/or submission, and redundancies have been completely observed by the authors.

\section{7- References}

[1] Beňo Michal, and Soňa Ferenčíková. “The Future of Work is e-Work.” 14th IWKM 2019, (7-8 November 2019): 6-20.

[2] Hossen, Md. Miraj, Mareum Begum, and Chen Zhixia. "Present Status of Organizational Work-Life Balance Practices in Bangladesh: Employees Expectation and Organizational Arrangements." Journal of Eastern European and Central Asian Research 5, no. 1 (April 20, 2018). doi:10.15549/jeecar.v5i1.199.

[3] Wang, Heli C., Jinyu He, and Joseph T. Mahoney. "Firm-Specific Knowledge Resources and Competitive Advantage: The Roles of Economic- and Relationship-Based Employee Governance Mechanisms.” Strategic Management Journal 30, no. 12 (December 2009): 1265-1285. doi:10.1002/smj.787.

[4] Kevin Daniels, David A. "Managing Telework: Perspectives from Human Resource Management and Work Psychology.” R \& D Enterprise: Asia Pacific 3, no. 4 (October 2000): 37-38. doi:10.1080/14401266.2000.11001122.

[5] Allen, Tammy D., Ryan C. Johnson, Kaitlin M. Kiburz, and Kristen M. Shockley. "Work-Family Conflict and Flexible Work Arrangements: Deconstructing Flexibility.” Personnel Psychology 66, no. 2 (November 30, 2012): $345-376$. doi:10.1111/peps.12012.

[6] Employed persons working from home as a percentage of the total employment, by sex, age and professional status (\%), Available online: https://ec.europa.eu/eurostat/databrowser/view/lfsa_ehomp/default/table?lang=en (accessed on 26 December 2020).

[7] Beno, Michal. "Transformation of Human Labour from Stone Age to Information Age." Lecture Notes in Computer Science (2018): 205-216. doi:10.1007/978-3-319-97163-6_17.

[8] Normand, T. Sharon-Lise. "Meta-analysis: formulating, evaluating, combining, and reporting." Statistics in medicine 18, no. 3 (January 21, 1999): 321-359. doi.org/10.1002/(SICI)1097-0258(19990215)18:3<321::AID-SIM28>3.0.CO;2-P.

[9] Shelby, Lori B., and Jerry J. Vaske. "Understanding Meta-Analysis: A Review of the Methodological Literature." Leisure Sciences 30, no. 2 (March 10, 2008): 96-110. doi:10.1080/01490400701881366.

[10] Aldine, Available online: https://www.collinsdictionary.com/dictionary/english/aldine, (accessed on 26 December 2020).

[11] Beno, Michal. "An Empirical Study on Teleworking among Slovakia's Office-Based Academics." In 2018 IEEE International Conference on Computational Science and Engineering (CSE), IEEE, (2018): 164-170. doi:10.1109/CSE.2018.00030. 
[12] Beňo, Michal. "Working in the Virtual World - an approach to the Home Office Business Model Analysis." Ad Alta: Journal of Interdisciplinary Research 8, no. 1 (2018): 25-36.

[13] Tim Bentley, “The Trans-Tasman Telework Survey,”, (2013) Available online: https://workresearch.aut.ac.nz/_data/assets/ pdf_file/0018/34209/trans-tasman-telework-survey-report-Final-December-2013.pdf (accessed on 26 December 2020).

[14] Baruch, Yehuda. "Teleworking: Benefits and Pitfalls as Perceived by Professionals and Managers.” New Technology, Work and Employment 15, no. 1 (March 2000): 34-49. doi:10.1111/1468-005x.00063.

[15] Duxbury, Linda, Christopher Higgins, and Derrick Neufeld. "Telework and the balance between work and family: is telework part of the problem or part of the solution?" ACM, The Virtual workplace (February 1998): 218-255.

[16] Forgacs, Tamas. "Empirical research findings on telework: Management experiences and attitudes." Business and Economic Horizons 1, no. 1 (April 2010): 6-13.

[17] Jennifer A. Guarino and Julie A. Bouffard. "Evaluating the success of Telecommuting at the Census Bureau.” Available online: http://citeseerx.ist.psu.edu/viewdoc/download?doi=10.1.1.380.4305\&rep=rep1\&type=pdf (accessed on 26 December 2020).

[18] Hartman, Richard I., Charles R. Stoner, and Raj Arora. “An Investigation of Selected Variables Affecting Telecommuting Productivity and Satisfaction.” Journal of Business and Psychology 6, no. 2 (1991): 207-225. doi:10.1007/bf01126709.

[19] Hawkins, M., L. Soe, and Lara Preiser-Houy. "The effectiveness of telecommuting for the employee, employer and society." Boeing Corporation (1999): 88-96.

[20] Hill, E. Jeffrey, Brent C. Miller, Sara P. Weiner, and Joe Colihan. "Influences of the Virtual Office on Aspects of Work and Work/Life Balance.” Personnel Psychology 51, no. 3 (September 1998): 667-683. doi:10.1111/j.1744-6570.1998.tb00256.x.

[21] Hill, E.Jeffrey, Maria Ferris, and Vjollca Märtinson. "Does It Matter Where You Work? A Comparison of How Three Work Venues (traditional Office, Virtual Office, and Home Office) Influence Aspects of Work and Personal/family Life.” Journal of Vocational Behavior 63, no. 2 (October 2003): 220-241. doi:10.1016/s0001-8791(03)00042-3.

[22] Hornung, Severin, and Jürgen Glaser. "Home-Based Telecommuting and Quality of Life: Further Evidence on an EmployeeOriented Human Resource Practice.” Psychological Reports 104, no. 2 (April 2009): 395-402. doi:10.2466/pr0.104.2.395-402.

[23] Masuda, Aline D., Steven A.Y. Poelmans, Tammy D. Allen, Paul E. Spector, Laurent M. Lapierre, Cary L. Cooper, Nureya Abarca, et al. "Flexible Work Arrangements Availability and Their Relationship with Work-to-Family Conflict, Job Satisfaction, and Turnover Intentions: A Comparison of Three Country Clusters.” Applied Psychology 61, no. 1 (June 5, 2011): 1-29. doi:10.1111/j.1464-0597.2011.00453.x.

[24] Mungamia, A. K., Esther Wangithi Waiganjo, and John M. Kihoro. "Influence of flexible work arrangement on organizational performance in the banking industry in Kenya." International Journal of Academic Research in Business and Social Sciences6, no. 7, (2016): 159172.

[25] Pyöriä, Pasi. "Knowledge Work in Distributed Environments: Issues and Illusions.” New Technology, Work and Employment 18, no. 3 (October 2, 2003): 166-180. doi:10.1111/1468-005x.00119.

[26] Raghuram, Sumita, and Batia Wiesenfeld. "Work-Nonwork Conflict and Job Stress among Virtual Workers." Human Resource Management 43, no. 2-3 (2004): 259-277. doi:10.1002/hrm.20019.

[27] Stavrou, Eleni T. "Flexible Work Bundles and Organizational Competitiveness: a Cross-National Study of the European Work Context." Journal of Organizational Behavior 26, no. 8 (December 2005): 923-947. doi:10.1002/job.356.

[28] Ten Brummelhuis, L. Lieke, Arnold B. Bakker, Jorn Hetland, and Liesbeth Keulemans. "Do new ways of working foster work engagement?" Psicothema 24, no. 1 (February 2012): 113-120.

[29] Tremblay, Diane - Gabrielle. "Balancing Work and Family with Telework? Organizational Issues and Challenges for Women and Managers.” Women in Management Review 17, no. 3/4 (May 2002): 157-170. doi:10.1108/09649420210425309.

[30] Tremblay, Diane Gabrielle, and Laurence Thomsin. "Telework and Mobile Working: Analysis of Its Benefits and Drawbacks." International Journal of Work Innovation 1, no. 1 (2012): 100-13. doi:10.1504/ijwi.2012.047995.

[31] Shafizadeh, Kevan R., Patricia L. Mokhtarian, Debbie A. Niemeier, and Ilan Salomon. "The costs and benefits of home-based telecommuting.", California PATH Research Report, UCB-ITS-PRR-2000-20, (2000).

[32] Monteiro, Natália P., Odd Rune Straume, and Marieta Valente. Does remote work improve or impair firm labour productivity? Longitudinal evidence from. No. 14/2019. NIPE-Universidade do Minho, (2019).

[33] Costa, Giovanni, Samantha Sartori, and Torbjorn Åkerstedt. "Influence of Flexibility and Variability of Working Hours on Health and Well - Being." Chronobiology International 23, no. $6 \quad$ (January 2006): 1125-1137. doi:10.1080/07420520601087491..

[34] Nijp, Hylco H, Debby GJ Beckers, Sabine AE Geurts, Philip Tucker, and Michiel AJ Kompier. "Systematic Review on the Association between Employee Worktime Control and Work-non-Work Balance, Health and Well-Being, and Job-Related Outcomes.” Scandinavian Journal of Work, Environment \& Health 38, no. 4 (June 6, 2012): 299-313. doi:10.5271/sjweh.3307. 
[35] Lupu, Valentina-Lidia. "Teleworking and Its Benefits on Work-Life Balance." 4th International Multidisciplinary Scientific Conference on Social Sciences and Arts SGEM2017, Modern Science (August 20, 2017): 693-700. doi:10.5593/sgemsocial2017/12/s02.087.

[36] Ford, Robert C., and Michael A. Butts. "Is your organization ready for telecommuting?." SAM Advanced Management Journal 56, no. 4 (Autumn 1991): 19.

[37] Beno, Michal. "Home-based Telework and the Role of Gender - Results of a Study in Austria." AIS, CONF-IRM 2019 Proceedings (2019): 12.

[38] Telecommuting Can Save Businesses Money, Available online: https://onlinemasters.ohio.edu/blog/telecommuting-can-savebusinesses-money/ (accessed on 24 December 2020).

[39] Latest Work-At-Home/Telecommuting/Mobile Work/Remote Work Statistics, Available online: https://globalworkplaceanalytics.com/telecommuting-statistics (accessed on 26 December 2020).

[40] Garg, Ajay K, and Jan van der Rijst. "The Benefits and Pitfalls of Employees Working from Home: Study of a Private Company in South Africa." Corporate Board Role Duties and Composition 11, no. 2 (2015): 36-49. doi:10.22495/cbv11i2art3.

[41] Raišienè, Agota Giedrè, Violeta Rapuano, Kristina Varkulevičiūtè, and Katarína Stachová. "Working from Home-Who Is Happy? A Survey of Lithuania's Employees during the COVID-19 Quarantine Period.” Sustainability 12, no. 13 (July 1, 2020): 5332. doi:10.3390/su12135332.

[42] Sakpere, Aderonke Busayo, Ifedolapo Olanipekun, Wilson Sakpere, and Ifeoluwatayo Adeseye Ige. "Work Productivity in the Period of COVID-19 Pandemic and Lockdown: A Developing World Perspective." Proceedings of the Nigerian Academy of Science (Special Edition on Covid-19) 13, no. 1 (2020). doi:10.5423/pngas.v13i1s.215.

[43] Harpaz, Itzhak. “Advantages and Disadvantages of Telecommuting for the Individual, Organization and Society.” Work Study 51, no. 2 (April 2002): 74-80. doi:10.1108/00438020210418791.

[44] Tremblay, Diane Gabrielle, and Laurence Thomsin. "Telework and Mobile Working: Analysis of Its Benefits and Drawbacks." International Journal of Work Innovation 1, no. 1 (2012): 100-113. doi:10.1504/ijwi.2012.047995. 